\title{
DELAYED BEHAVIORAL EFFECTS OF SH-I-048A, A NOVEL NONSELECTIVE POSITIVE MODULATOR OF GABA RECEPTORS, AFTER PERIPHERAL NERVE INJURY IN RATS
}

\author{
OBRADOVIĆ Lj Aleksandar ${ }^{1 *}$, JOKSIMOVIĆ Srđan², POE M Michael’, TIMIĆ \\ Tamara $^{2}$, COOK M James ${ }^{3}$, SAVIĆ M Miroslav ${ }^{2}$ \\ ${ }^{1}$ Department of Physiology, Faculty of Pharmacy, University of Belgrade, Belgrade, Serbia; ${ }^{2}$ Department \\ of Pharmacology, Faculty of Pharmacy, University of Belgrade, Belgrade, Serbia; ${ }^{3}$ Department of \\ Chemistry and Biochemistry, University of Wisconsin-Milwaukee, Milwaukee, Wisconsin, USA
}

(Received 31 December 2013; Accepted 13 March 2014)

The complex clinical picture of mono-neuropathy following injury of peripheral nerve is often accompanied by changes in the patients' affective states. It has been shown that positive allosteric modulators of $\mathrm{GABA}_{\mathrm{A}}$ receptors can decrease nociceptive transmission in animal pain models. However, recent findings suggest a possibility that at least some of the antinociceptive effects of benzodiazepines, related to neuropathic painful stimuli, may to a significant degree be a consequence of their anxiolytic action.

In this study we evaluated the possible delayed effects of SH-I-048A, a newlysynthesized high-efficacy nonselective positive modulator of $\mathrm{GABA}_{\mathrm{A}}$ receptors, on anxiety-like behavior and locomotor activity in Wistar rats with a previously induced peripheral nerve injury.

Assessment of behavioral parameters, using spontaneous locomotor activity and elevated plus maze tests, was performed $48 \mathrm{~h}$ after completion of single-day threei.p. injections treatment consisting of zero, one, two or three doses of SH-I-048A (10 mg/kg).

In general, rats' behavior observed $72 \mathrm{~h}$ after a moderate peripheral nerve injury did not indicate the persistence of sequelae of mono-neuropathic pain. The rats treated with three doses of $\mathrm{SH}-\mathrm{I}-048 \mathrm{~A}$ displayed an enhanced immobility time in the locomotor activity test, without concomitant decrease of the total distance traveled. On the other hand, in the group treated with two doses of $\mathrm{SH}-$ I-048A, a decrease in the emotional reactivity in the elevated plus maze test was observed. Subtle changes in the regimen of dosing of SH-I-048A affect locomotor activity and anxiety-related behavior in animals with peripheral nerve injury.

Key words: benzodiazepines elevated plus maze, nerve crush injury, spontaneous locomotor activity, $W$ istar rats

\section{INTRODUCTION}

Complex pathophysiology of peripheral nerve injury is poorly understood and is usually accompanied with a significant comorbid burden, which commonly consists

* Corresponding author: e-mail: aleksaobradovic@gmail.com 
of changes in the affective state (principally depression or anxiety), among a myriad of other behavioral disturbances [1]. The data regarding the importance of these additional influences in the genesis of neuroplastic imprinting processes related to pathological nociceptive memory formation are insufficient; in any case, they are modulated by changes in the GABA neurotransmission in the spinal cord [2]. In this vein, it was shown that $\mathrm{GABA}_{\mathrm{A}}$ receptor positive allosteric modulators, such as diazepam, attenuate nociceptive transmission in animal models of neuropathic pain $[3,4]$. Nevertheless, a recent detailed analysis of benzodiazepine (BZ) influence on the behavior of rats subjected to an acute nociception-inducing stimulus, such as the hotplate test, demonstrated that the effects of these drugs on the structure of the rat's response to pain are more likely attributable to anxiolysis than pain modulation [5].

Despite their limitations, BZs are still in widespread use for the treatment of anxiety disorders and insomnia [6]. They act through those populations of GABA receptors which contain an $\alpha_{1}, \alpha_{2}, \alpha_{3}$ or $\alpha_{5}$ subunit adjacent to the $\gamma_{2}$ subunit [7]. Development of ligands non-selective in affinity and efficacy at GABA receptors with a low potential for motor deficits in animals [8,9], has been postulated as a valuable concept in the treatment of both pain and comorbid anxiety side effects. On the other hand, studies with mice carrying point mutations at one of the benzodiazepine-sensitive $\mathrm{GABA}_{\mathrm{A}}$ receptors have attributed sedation to the selective activity of $\alpha_{1}$-containing $\mathrm{GABA}_{\mathrm{A}}$ receptors [10]. L-838,417, a compound with high affinity for all four subtypes of sensitive $\mathrm{GABA}_{\mathrm{A}}$ receptors, but partially effective only at the $\alpha_{2}-, \alpha_{3}-$, and $\alpha_{5} \mathrm{GABA}_{\mathrm{A}}$ receptor-subtypes [11], exerted an anti-hyperalgesic action in wild type rats in models of inflammatory and neuropathic pain, without unwanted sedation, motor impairment, and tolerance development [12]. Furthermore, this ligand reduced the activity of brain areas related to the sensory and discriminative component of pain (the medial thalamus and contralateral primary sensory cortex) or its emotional dimension (limbic system and frontal association cortex) [12].

SH-I-048A is a newly-synthesized positive modulator of the $\mathrm{GABA}_{\mathrm{A}}$ receptor characterized by high affinity and high efficacy at all four BZ-sensitive $G_{A B} A_{A}$ receptors [13]. Biological and electrophysiological screening has shown that SHligands in general share the majority of the general properties of diazepam, with some distinctiveness, possibly attributable to the subtle differences in action at the four populations of receptors $[14,15]$. This and similar findings indicate that among the nonselective agonists of $\mathrm{GABA}_{\mathrm{A}}$ receptors, even the finest variation in the activity profile at the different subunit composition of the functional $\mathrm{GABA}_{\mathrm{A}}$ receptor can grossly affect their functional properties and could also potentially provide therapeutic benefit by reducing certain symptoms without producing unwanted sedation and delayed motor side effects. More specifically, SH-I-048A in a wide range of doses $(0.5-10 \mathrm{mg} / \mathrm{kg})$ exerted a diminished potential to induce anxiolysis and memory impairment, while repeatedly administered in three $10 \mathrm{mg} / \mathrm{kg}$ doses during 24 hour periods after nerve crash injury had reversed the mechanical hyperalgesia without substantial motor incapacitation. 
In the present study we tested the possible delayed effects of SH-I-048A on anxietylike behavior and locomotor activity in rats with a previously induced peripheral nerve injury, using elevated plus-maze and spontaneous locomotor activity test, respectively.

\section{MATERIAL AND METHODS}

\section{Drugs}

The novel compound SH-I-048A ((S,E)-7-bromo-5-(2-fluorophenyl)-3-methyl1Hbenzo[e][1,4]diazepin-2(3H)-one) was synthesized at the Department of Chemistry and Biochemistry, University of Wisconsin-Milwaukee. SH-I-048 was dissolved/ suspended in a solvent containing $85 \%$ distilled water, $14 \%$ propylene glycol, and 1\% Tween-80 and was administered intraperitoneally (IP) in a volume of $1 \mathrm{ml} / \mathrm{kg}$.

\section{Animals}

Experiments were carried out on male Wistar rats (Military Farm, Belgrade, Serbia), weighing 180-200 $\mathrm{g}$ at the beginning of the trial. All procedures in the study conformed to EEC Directive 86/609 and were approved by the Ethical Committee on Animal Experimentation of the Faculty of Pharmacy in Belgrade. The rats were group-housed (four per cage) in transparent plastic cages with tap water and food pellets available ad libitum and kept under standard laboratory conditions. The temperature of the animal room was $22 \pm 1{ }^{\circ} \mathrm{C}$, relative humidity $40-70 \%$, illumination $120 \mathrm{~lx}$, and 12/12 h light/ dark period (light on at 6:00 h). All handling, daily administration of treatment and testing took place during the light period of the cycle, between 9:00 and 13:00 h.

\section{Peripheral nerve injury model}

A crush injury to the right sciatic nerve was performed in order to produce the peripheral nerve injury model. Beforehand the rats were anesthetized with ketamine solution (10\% Ketamidor, Richter Pharma Ag, Wels, Austria). After the right external thigh and buttock area had been shaved, the skin was properly prepared with an antiseptic solution and alcohol, and a small incision was made. The $m$. vastus lateralis and $m$. biceps femoralis were bluntly separated at the mid-thigh level. The nerve was kept in situ. At approximately $7 \mathrm{~mm}$ from the point of its emergence, the common sciatic nerve was mobilized and traumatized by a single 30-s crush with a serrated hemostat [16]. After surgery animals were separated in four groups. Treatments were administered three times during a $24 \mathrm{~h}$ period (immediately after surgery, after 12 hours and finally after $23 \mathrm{~h}$ ). The treatment groups were: solvent three times (vehicle group); one dose of SH-I-048A (10 mg/ kg) and solvent two times; two doses of SH-I-048A (10 mg/kg) and solvent once and three doses of SH-I-048A (10 mg/kg) (Figure 1). A control group, consisting of sham-operated or naïve rats, was not used in the present experiment; instead of that, we opted to present in figures the mean 
control values for the given parameter, obtained from at least 30 animals treated once with the same solvent in previous experiments performed in our laboratory [17-19].

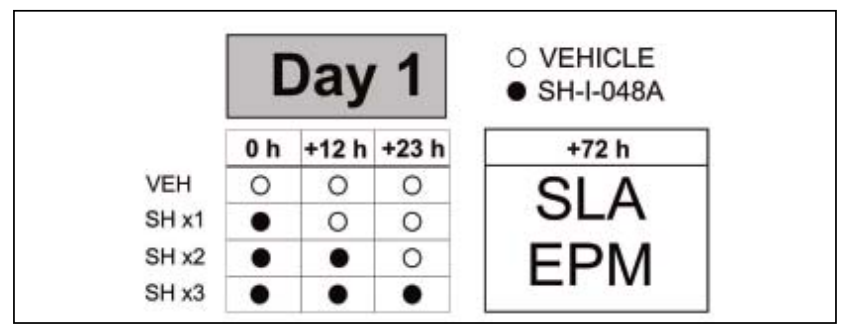

Figure 1. The scheme of experimental procedure, indicating treatments administered immediately after surgery $(0 \mathrm{~h}), 12 \mathrm{~h}$ later $(+12 \mathrm{~h})$ and after $23 \mathrm{~h}(+23 \mathrm{~h})$. Close circle represent one dose of $10 \mathrm{mg} / \mathrm{kg}$ of SH-I-048A; open circle represent vehiculum. SLA - spontaneous locomotor activity. EPM elevated plus maze. Number of animals per each treatment group was 5 or 6

\section{Spontaneous locomotor activity}

Single rats were placed in a clear Plexiglas chamber $(40$ x 25 x $35 \mathrm{~cm}) 72 \mathrm{~h}$ after surgery and corresponding treatment. Activity under dim red light (20 lux) was recorded for a total of $30 \mathrm{~min}$, without any habituation period, using ANY-maze software. The observed selected parameters were the distance traveled and the time immobile, measured during $30 \mathrm{~min}$, as well as in 5-min intervals.

\section{Elevated plus-maze}

The elevated plus-maze (EPM) apparatus was constructed of sheet metal, with a black rubber floor. It consisted of two opposed open arms $(50 \times 10 \mathrm{~cm})$ with ledges (0.3 cm high) and two opposed enclosed arms $(50 \times 10 \times 40 \mathrm{~cm})$, connected by the junction area $(10 \times 10 \mathrm{~cm})$. The whole apparatus was elevated $50 \mathrm{~cm}$ above the floor. Illumination in the experimental room was provided with one red neon tube fixed on the ceiling above the maze. Light intensity was $10 \mathrm{~lx}$ on the surface of the closed arms. Immediately after SLA (spontaneous locomotor activity) test, single rats were placed in the centre of the maze, facing one of the enclosed arms and were allowed to freely explore the apparatus during 5 minutes. The standard spatiotemporal variables were recorded and analyzed using the ANY-maze Video Tracking System software (Stoelting Co., Wood Dale, IL, USA) in accordance with our previous studies [17-19]. The parameters closely related to motor activity were the total distance travelled and closed arm entries. The primary indices of anxiety were the percentage of open arm entries and the percentage of the time spent on open arms. An entry into an open arm or closed arm was scored when $90 \%$ of the observed animal crossed the virtual line separating the neighboring zones, whereas an exit occurred when more than $90 \%$ of animal left the respective zone. 


\section{Statistical analysis}

All numerical data presented in the figures are given as the mean \pm SEM. Behavioral data sets were checked for homogeneity of variance and normality prior to analysis by one-way ANOVA. In order to assess the influence of treatment on locomotion in SLA test during six 5-min intervals we used a two-way ANOVA with repeated measures (Treatment as between-subject factor and Time as within-subject factor). Where applicable, Student-Newman-Keuls's (SNK) test for post hoc comparisons was also used. In the case of significant interaction, separate one-way ANOVAs were conducted to assess the influence of factor Treatment within individual levels of factor Time. Statistical analysis was performed with ANY-maze Video Tracking System software (Stoelting Co., Wood Dale, IL, USA) and Sigma Plot 11 (Systat Software Inc., Richmond, CA, USA). Differences were considered to be statistically significant for $\mathrm{p} \leq 0.05$.

\section{RESULTS}

\section{Spontaneous locomotor activity}

The influence of SH-I-048A on total distance traveled during $30 \mathrm{~min}$ of monitoring did not reach statistical significance, as assessed by a one-way $\operatorname{ANOVA}(F(3,19)=2.04$, $\mathrm{p}=0.143$; Figure 2a). However, there was a significant effect of treatment on the total

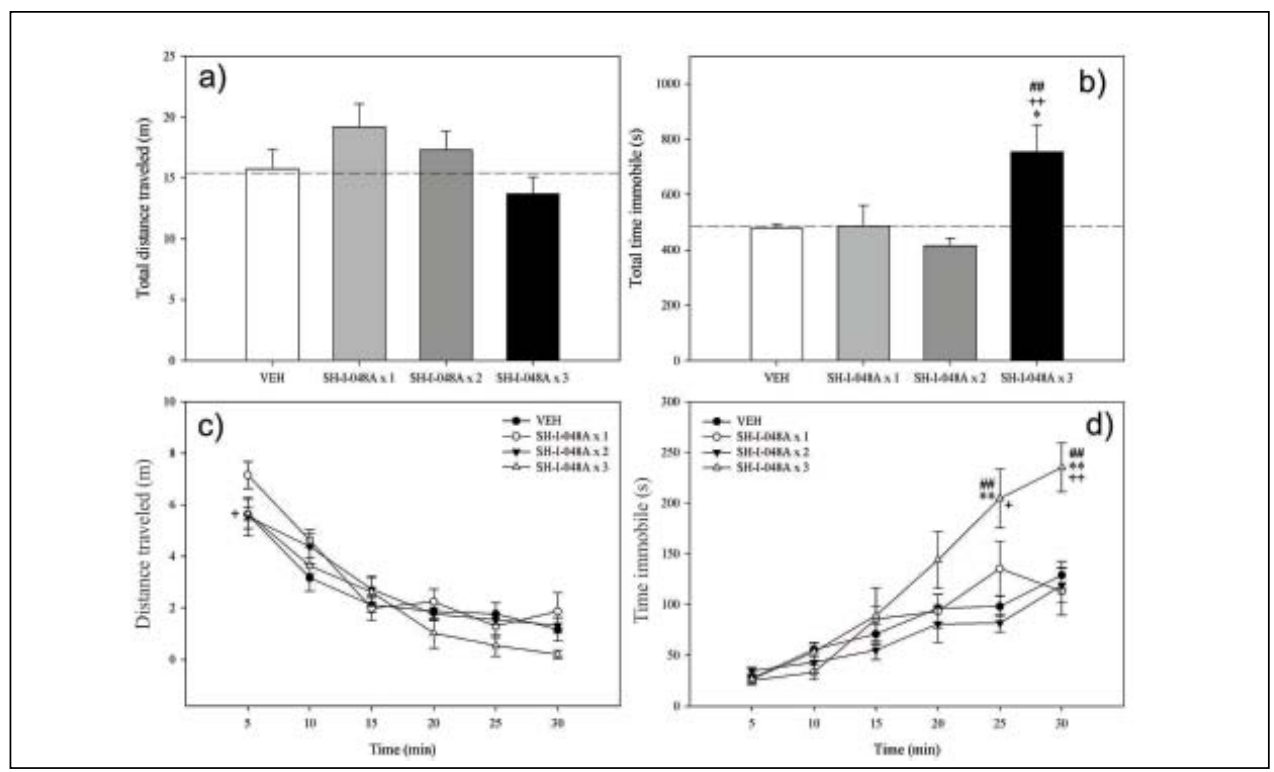

Figure 2. The effects of SH-I-048 on the a) total distance traveled, b) total time immobile, c) distance traveled in 5 min intervals, and d) time immobile in 5 min intervals in spontaneous locomotor activity. ${ }^{*} \mathrm{p}<0.05,{ }^{*} * \mathrm{p}<0.01$ compared to the vehiculum (VEH); $+\mathrm{p}<0.05,++$ $\mathrm{p}<0.01$ compared to the SH-I-048 x 1 group; \#\# $\mathrm{p}<0.01$ compared to the SH-I-048 $\times 2$ group. Dash lines in figures 2 and 3 represent the mean values of the given parameter in the control group from previous experiments performed in our laboratory 
time of immobility $(\mathrm{F}(3,19)=5.78, \mathrm{p}=0.006$; Figure $2 \mathrm{~b})$. SNK post hoc showed that rats treated with three doses of SH-I-048A spent more time in immobility compared to animals treated after injury with solvent only (vehicle group) $(\mathrm{p}=0.017)$, as well as to animals treated with two or one dose of SH-I-048A ( $p=0.007$ and $p=0.008$, respectively).

A two-way ANOVA with repeated measures applied on the data for the distance traveled during six 5-min intervals revealed a significant effect only for factor Time $(\mathrm{F}(5,95)=84.76, \mathrm{p}<0.001$; Figure $2 \mathrm{c})$. The same statistical analysis for the time of immobility revealed a significant effect for both factors, as well as for their interaction (Treatment: $\mathrm{F}(3,19)=5.78, \mathrm{p}=0.006$; Time: $\mathrm{F}(5,95)=48.82, \mathrm{p}<0.001$; Interaction: $\mathrm{F}(15,95)=4.15, \mathrm{p}<0.001 ;$ Figure $2 \mathrm{~d})$.

\section{Elevated plus-maze}

A one-way ANOVA showed a significant influence of treatment on the total distance traveled $(F(3,18)=6.86, p=0.003$; Figure $3 a)$, but not on the number of closed arm entries (Figure 3b). Rats treated with two doses of SH-I-048A had longer distances in regard to all three other groups, as assessed with post hoc SNK's test, demonstrating a profound influence on these activity-related parameters.

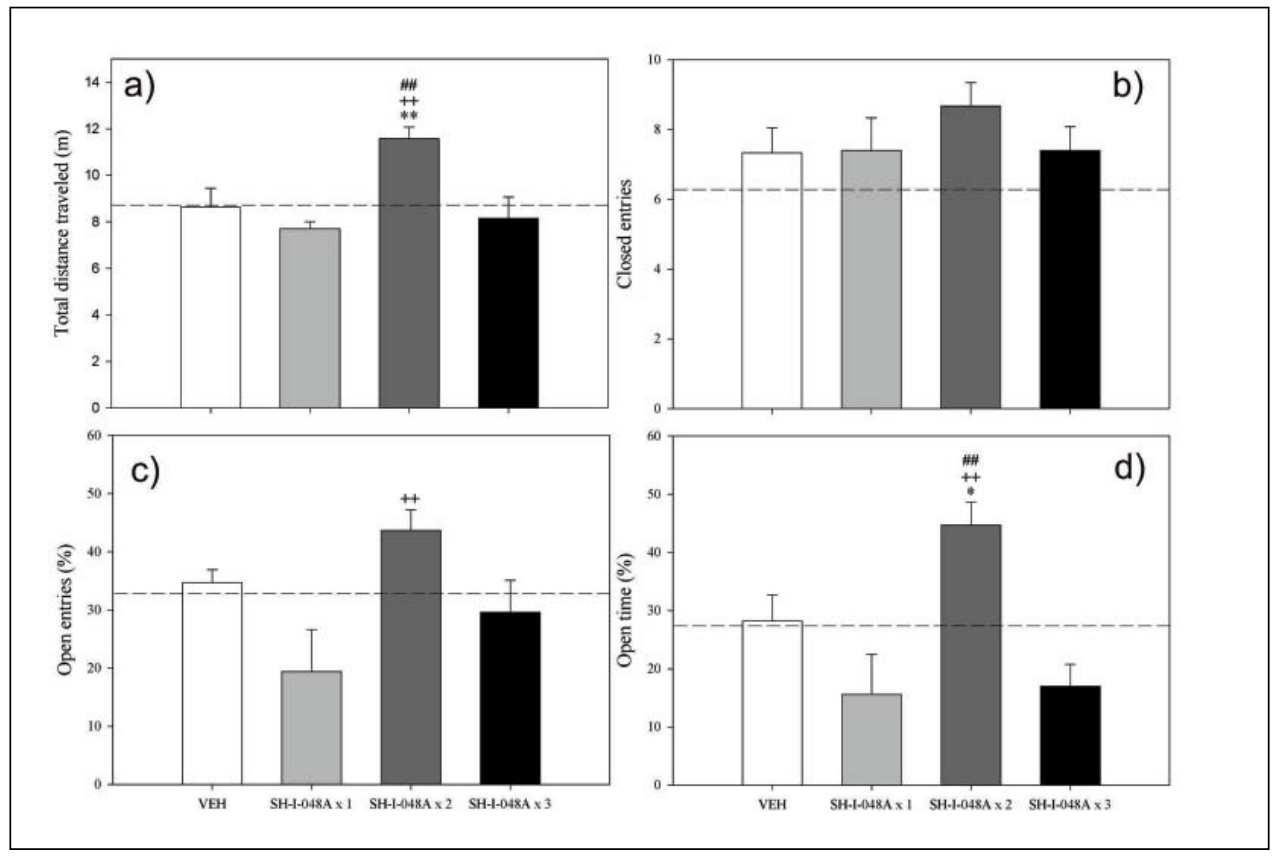

Figure 3. The effects of SH-I-048 on the a) total distance traveled, b) number of closed arm entries, c) percentage of open arm entries, and d) percentage of open time in the elevated plus-maze. ${ }^{*} \mathrm{p}<0.05,{ }^{* *} \mathrm{p}<0.01$ compared to the vehiculum $(\mathrm{VEH}) ;++\mathrm{p}<0.01$ compared to the SH-I-048 x 1 group; \#\# p<0.01 compared to the SH-I-048 x 3 group 
Regarding the anxiety-related parameters, one-way ANOVA revealed that the effect of treatment on the percentage of the time spent on open arms was significant $(\mathrm{F}(3,18)=7.86, \mathrm{p}=0.001$; Figure $3 \mathrm{c})$. SNK's post hoc test showed that rats treated with two doses of SH-I-048A spent significantly more time in open arms when compared to vehicle animals and those treated with three or one dose of SH-I-048A (respective $p$ values: $0.027,0.002$ and 0.003$)$. For the percentage of open arms entries, factor Treatment was also significant $(\mathrm{F}(3,18)=4.67, \mathrm{p}=0.014$; Figure $3 \mathrm{~d})$; there was a significant difference between rats treated with two doses compared to rats treated with only one dose of SH-I-048A ( $\mathrm{p}=0.009)$.

\section{DISCUSSION}

Acute injury of peripheral nervous tissue results in clear-cut distressing manifestations, involving most prominently a state of hyperalgesia, in animals as well as in humans [20]. In addition to its pathophysiological complexity and immense difficulty to diagnostically evaluate it in a clinical environment, the treatment of neuropathic pain also proved to be very challenging. It is becoming an increasingly arduous task to choose not only the suitable candidate among a number of different treatments for neuropathic pain, but also the right time and dosage regime [21]. To resolve this intricate issue considering the plentitude of mechanisms which mediate inflammatory and nociceptive processes generated by injury [22,23], in the last couple of years many studies have been designed to record and analyze the comprehensive behavioral status of experimental animals subjected to mechanical nerve injury, especially focusing on the recovery period, which is known to be very important in the process of consolidation of the pathological phenotype. One such model of peripheral nerve injury is that of the crush injury of $n$. ischiadicus in rats, which demonstrated feasibility in assessing possible modulatory influences of early interventions with distinct pharmacological tools. Among these possible interventions, one of the salient roles is suggested for GABA-ergic modulation [24].

On the other hand, studies aimed at assessing the general behavioral status of animals in a recovery period and the accompanying intervention are surprisingly rare [5]. Examination of animals in this phase would give a useful set of information, having in mind that signs of distress, such are changes in anxiety level or general locomotor activity, may affect the well-being and overall prognosis, both in animals [25], and in humans [26]. The results of the present crush injury study suggest that acute nerve injury of moderate intensity is connected with a generally normal range of locomotor and emotional reactivity output in placebo-treated rats, as assessed through the SLA and EPM tests $72 \mathrm{~h}$ after surgery. However, the animals treated with a novel benzodiazepine-like compound, SH-I-048A, characterized by high affinity and efficacy at all four populations of BZ-sensitive $\mathrm{GABA}_{\mathrm{A}}$ receptors, have displayed an unexpected array of differences in behavioral activity. Namely, the rats previously treated twice with SH-I-048A at $10 \mathrm{mg} / \mathrm{kg}$ i.p. were apparently less anxious, i.e. less 
emotionally reactive when faced with the choice between open and closed arms of the maze, without clear changes in general activity, as assessed through closed arm entries in the EPM and the parameters from the SLA test. Furthermore, the animals treated with three doses of SH-I-048A at $10 \mathrm{mg} / \mathrm{kg}$, displayed an unusual pattern of decreased locomotor activity, manifested through an increased time of immobility, without an accompanying decrease of total distance traveled. Moreover, an analysis of activity in six 5-min bins revealed that the majority of the detected immobility was realized in the final 10 min of tracking, which is contrary to the sedative action induced by acute treatment with diazepam, observed as a rule in the first $15 \mathrm{~min}$, even without the habituation period, as was the case in the present study [27]. It is noteworthy to mention that additional kinetic investigation of SH-I-048A could possibly indicate the presence of very low residual concentrations of the compound in brain tissue $72 \mathrm{~h}$ after dosing, as demonstrated for other benzodiazepine-like compounds after application of similar doses. If that would be the case, the importance of choosing a ligand with a suitable subunit activity profile, as well as the right time and dosage regimen for its application, becomes even more significant in light of the fine tuning of neural plasticity related to the post-injury period and recovery $[28,29]$.

Our study is limited by the absence of methodological tools aimed at the objective assessment of injury recovery. Gross behavioral status of animals, assessed $72 \mathrm{~h}$ after crush injury was devoid of clear signs of distress. Nevertheless, more specific behavioral analysis demonstrated that animals treated moderately with a potent and effective benzodiazepine-like compound were in a behavioral status which could be regarded as desirable (decreased anxiety, normal locomotion) in the settings of the patient's recovery after an acute nerve injury. On the other hand, a more intense previous treatment, in animals dosed three times, was connected with an apparently less desirable profile, characterized by an increased immobility.

\section{CONCLUSION}

In conclusion, the present study suggests that the behavioral output of animals previously subjected to peripheral nerve injury is affected by subtle changes in the regimen of dosing the positive modulator of $\mathrm{GABA}_{\mathrm{A}}$ receptors, and it supports the need for refining any treatments aimed at supporting the injured patients, which may have some beneficial delayed effects.

\section{REFERENCES}

1. Gormsen L, Rosenberg R, Bach FW, Jensen TS: Depression, anxiety, health-related quality of life and pain in patients with chronic fibromyalgia and neuropathic pain. Eur J Pain 2010, 14:127.e1-8.

2. Munro G, Ahring PK, Mirza NR: Developing analgesics by enhancing spinal inhibition after injury: GABA A receptor subtypes as novel targets. Trends Pharmacol Sci 2009, 30:453-9. 
3. Knabl J, Zeilhofer UB, Crestani F, Rudolph U, Zeilhofer HU: Genuine antihyperalgesia by systemic diazepam revealed by experiments in $\mathrm{GABA}_{\mathrm{A}}$ receptor point-mutated mice. Pain 2009, 141:233-8.

4. Malan TP, Mata HP, Porreca F: Spinal GABA(A) and GABA(B) receptor pharmacology in a rat model of neuropathic pain. Anesthesiology 2002, 96:1161-7.

5. Casarrubea M, Sorbera F, Santangelo A, Crescimanno G: The effects of diazepam on the behavioral structure of the rat's response to pain in the hot-plate test: anxiolysis vs. pain modulation. Neuropharmacology 2012, 63:310-21.

6. Stahl SM: Don't ask, don't tell, but benzodiazepines are still the leading treatments for anxiety disorder. J Clin Psychiatry 2002, 63:756-7.

7. Sieghart W, Ernst M: Heterogeneity of GABAA receptors: revived interest in the development of subtype-selective drugs. Curr Med Chem - Central Nervous System Agents 2005, 5:217-242.

8. Auta J, Kadriu B, Giusti P, Costa E, Guidotti A. Anticonvulsant, anxiolytic, and nonsedating actions of imidazenil and other imidazo-benzodiazepine carboxamide derivatives. Pharmacol Biochem Behav 2010, 95:383-9.

9. Rabe H, Kronbach C, Rundfeldt C, Lüddens H: The novel anxiolytic ELB139 displays selectivity to recombinant $\mathrm{GABA}(\mathrm{A})$ receptors different from diazepam. Neuropharmacology 2007, 52:796-801.

10. Rudolph U, Crestani F, Benke D, Brünig I, Benson JA, Fritschy JM, Martin JR, Bluethmann $\mathrm{H}$, Möhler H: Benzodiazepine actions mediated by specific gamma-aminobutyric acid(A) receptor subtypes. Nature 1999, 401:796-800.

11. McKernan RM, Rosahl TW, Reynolds DS, Sur C, Wafford KA, Atack JR, et al: Sedative but not anxiolytic properties of benzodiazepines are mediated by the GABA(A) receptor alpha1 subtype. Nat Neurosci 2000, 3:587-92.

12. Knabl J, Witschi R, Hösl K, Reinold H, Zeilhofer UB, Ahmadi S, et al: Reversal of pathological pain through specific spinal GABA ${ }_{A}$ receptor subtypes. Nature 2008, 451:330 4.13 .

13. Cook JM, Huang S, Sarma PVVS, Zhang C, Zhou H; Wisys Technology Found Inc, James M Cook, Hao Zhou, Shengming Huang, P V V S Sarma, Chunchun Zhang, assignee. Stereospecific anxiolytic and anticonvulsant agents with reduced muscle-relaxant, sedativehypnotic and ataxic effects. United States patent US WO2006004945 A1 2006 Jan 12. [http://patentscope.wipo.int/search/en/WO2006004945]

14. Drexler B, Zinser S, Huang S, Poe MM, Rudolph U, Cook JM, Antkowiak B: Enhancing the function of alpha5-subunit-containing GABAA receptors promotes action potential firing of neocortical neurons during up-states. Eur J Pharmacology 2013, 5:703.

15. Gill KM, Lodge DJ, Cook JM, Aras S, Grace AA: A novel $\alpha 5$ GABA(A)R-positive allosteric modulator reverses hyperactivation of the dopamine system in the MAM model of schizophrenia. Neuropsychopharmacology 2011, 36:1903-11.

16. Bridge PM, Ball DJ, Mackinnon SE, Nakao Y, Brandt K, Hunter DA, et al: Nerve crush injuries—a model for axonotmesis. Exp Neurol 1994, 127:284-90.

17. Savić MM, Huang S, Furtmüller R, Clayton T, Huck S, Obradović DI, et al: Are GABAA receptors containing alpha5 subunits contributing to the sedative properties of benzodiazepine site agonists? Neuropsychopharmacology 2008, 33:332-9.

18. Savić MM, Majumder S, Huang S, Edwankar RV, Furtmüller R, Joksimović S, et al: Novel positive allosteric modulators of GABAA receptors: do subtle differences in activity 
at alpha1 plus alpha5 versus alpha2 plus alpha3 subunits account for dissimilarities in behavioral effects in rats? Prog Neuropsychopharmacol Biol Psychiatry 2010, 34:376-86.

19. Savić MM, Obradović DI, Ugresić ND, Cook JM, Yin W, Bokonjić DR: Bidirectional effects of benzodiazepine binding site ligands in the elevated plus-maze: differential antagonism by flumazenil and beta-CCt. Pharmacol Biochem Behav 2004, 79:279-90.

20. Dworkin RH: An overview of neuropathic pain: syndromes, symptoms, signs, and several mechanisms. Clin J Pain 2002, 18:343-9.

21. Finnerup NB, Sindrup SH, Jensen TS: The evidence for pharmacological treatment of neuropathic pain. Pain 2010, 150:573-81.

22. O'Connor AB, Dworkin RH: Treatment of neuropathic pain: an overview of recent guidelines. Am J Med 2009, 122:S22-32.

23. Ellis A, Bennett DL: Neuroinflammation and the generation of neuropathic pain. Br J Anaesth 2013, 111:26-37.

24. Naik AK, Latham JR, Obradovic A, Jevtovic-Todorovic V: Dorsal root ganglion application of muscimol prevents hyperalgesia and stimulates myelin protein expression after sciatic nerve injury in rats. Anesth Analg 2012, 114:674-82.

25. Huston JP, Schulz D, Topic B: Toward an animal model of extinction-induced despair: focus on aging and physiological indices. J Neural Transm 2009, 116:1029-36.

26. Ryan CG, Gray HG, Newton M, Granat MH: The relationship between psychological distress and free-living physical activity in individuals with chronic low back pain. Man Ther 2010, 15:185-9.

27. Divljaković J, Milić M, Timić T, Savić MM: Tolerance liability of diazepam is dependent on the dose used for protracted treatment. Pharmacol Rep 2012, 64:1116-25.

28. Friedman H, Abernethy DR, Greenblatt DJ, Shader RI: The pharmacokinetics of diazepam and desmethyldiazepam in rat brain and plasma. Psychopharmacology 1986, 88:267-70.

29. Samardžić J, Puškaš L, Obradović M, Lazić-Puškaš D, Obradović D: Antidepressant effects of an inverse agonist selective for $\alpha 5$ GABA-A receptors in the rat forced swim test, Acta Vet (Beograd) 2014, 64(1):52-60.

\title{
ODLOŽENI BIHEJVIORALNI EFEKTI SH-I-048A, NOVOG NESELEKTIVNOG POZITIVNOG MODULATORA GABA RECEPTORA, NAKON POVREDE PERIFERNOG NERVA PACOVA
}

\author{
OBRADOVIĆ Lj Aleksandar, JOKSIMOVIĆ Srđan, POE M Michael, TIMIĆ \\ Tamara, COOK M James, SAVIĆ M Miroslav
}

Kompleksna klinička slika neuropatije nakon povrede perifernog nerva često je praćena i promenama afektivnog stanja pacijenata. $U$ animalnim modelima bola pokazano je da pozitivni alosterni modulatori GABA receptora mogu da smanje nociceptivnu transmisiju. Međutim, skorašnji nalazi ukazuju i na mogućnost da je prividni 
antinociceptivni efekat benzodiazepina nakon delovanja akutnog bolnog stimulusa u značajnoj meri posledica anksiolitičnog efekta.

U ovoj studiji ispitani su mogući odloženi efekti novosintetisanog, neselektivnog liganda $\mathrm{GABA}_{\mathrm{A}}$ receptora (SH-I-048A) na lokomotornu aktivnost i ponašanje u vezi sa anksioznošću kod pacova soja $W$ istar prethodno podvrgnutih povredi perifernog nerva.

Procena bihejvioralnih parametara sprovedena je testovima spontane lokomotorne aktivnosti i uzdignutog plus lavirinta 48 sati nakon što su životinje u periodu od 24 sata primile rastvarač, jednu, dve ili tri doze SH-I-048A (10 mg/kg).

Generalno, ponašanje pacova praćeno 72 sata nakon umerene povrede perifernog nerva nije ukazivalo na prisustvo perzistentnih posledica neuropatskog bola. Pacovi prethodno tretirani sa tri doze SH-I-048A ispoljili su povećano vreme imobilnosti u testu lokomotorne aktivnosti, bez značajnog smanjenja ukupnog pređenog puta. S druge strane, u grupi koja je tretirana sa dve doze SH-I-048A zapažena je smanjena emocionalna reaktivnost u uzdignutom plus lavirintu.

Kod životinja sa povredom perifernog nerva, suptilne razlike u režimu doziranja pozitivnog modulatora $G_{A B A}$, mogu značajno da utiču na ponašanje vezano za lomotornu aktivnost i nivo anksioznosti. 